\title{
Catechol O-Methyltransferase
}

National Cancer Institute

\section{Source}

National Cancer Institute. Catechol O-Methyltransferase. NCI Thesaurus. Code C16387.

Catechol O-methyltransferase (271 aa, $\sim 30 \mathrm{kDa}$ ) is encoded by the human COMT gene.

This protein is involved in the metabolism of neurotransmitters. 